\title{
МОТИВАЦІЯ ВИБОРУ ПРОФЕСІї ЯК ВАЖЛИВИЙ ЧИННИК РОЗВИТКУ ТА СТАНОВЛЕННЯ ВЧИТЕЛЯ ІНФОРМАТИКИ
}

У статті охарактеризовано основні критеріі вибору випускником школи спечіальності «вчитель інформатики». Проаналізовано результати анкетування вчителів інформатики щодо важливості вибору освітнього напряму навчання, а також вплив на вибір професії зовнішніх та внутрішніх чинників.

Ключові слова: професія, вчитель інформатики, кваліфікаиійні напрями, підготовленість до профеciï, фаx.

В статье охарактеризованы основные критерии по выбору выпускником школь профессии квалификачии «учитель информатики». Проанализированы результаты опроса учителей информатики по важности выбора образовательного направления обучения, а также влияние на выбор профессии внешних и внутренних факторов.

Ключевые слова: профессия, учитель информатики, квалификащионные направления, подготовленность к профессии, специиальность.

The article outlines the main criteria for choosing the profession of «teacher of computer science». The importance of a letter of motivation for admission to higher education institutions in Ukraine and in European countries (on the example of the Republic of Poland) is shown. The results of the survey of informatics teachers on the importance of choosing the educational direction of study are presented; the influence of external and internal criteria on the choice of profession of computer science teacher is analyzed.

The survey identified the main areas of qualifications that respondents received after completing their university learning (the most involved in the survey were IT teachers); the most important criteria in choosing the direction of study (love for work with children and youth; high prestige of the profession; curiosity; case; closeness to the place of residence; family traditions; convenient access to the place of study; others) are analyzed. It was found that the largest number of responses concerned "curiosity of direction»; then came the answer - "love of working with children and young people» and "high prestige of the profession»; the least - «other reasons».

Respondents answered the re-choice of profession (62\% of those re-choosing the profession would choose the same field of education and the same institution). An analysis of the answers regarding trained IT teachers after completing their study at university for fulfilling their professional duties, $55 \%$ said «yes»; $43 \%$ said «yes». Based on the survey results announced problems with the conscious choice of profession «science teacher» and conclusions on the role of professional orientation of the future entrant. This article is a part of the results of the work on the implementation of research Rivne Regional Institute of Postgraduate Teacher Education.

Key words: profession, informatics teacher, qualification directions, professional readiness, profession.

Постановка проблеми. Зміни, що відбуваються в освіті, визначають не лише майбутнє України, а й безпосередньо долю випускників закладів загальної середньої освіти (далі - 33СО), які сьогодні стоять перед непростим вибором професії. Звичайно, готуючись до вступу, вони насамперед дослухаються до рекомендацій класного керівника, вчителів-предметників, шкільного психолога. Це питання обговорюється в сім'ях, самими старшокласниками, і чим ближче до закінчення школи, тим воно стає значущішим, а іноді й драматичним. Важливу роль при цьому відіграють заклади вищої освіти (далі - 3BO), які проводять із майбутніми абітурієнтами профорієнтаційну роботу.

Таким чином, свідоме ставлення до вибору професії - це мотивована спрямованість особистості на:

- усвідомлення соціального та особистого значення вибору професії;

- оволодіння системними профорієнтаційними знаннями;

- активні способи підготовки до майбутньої праці та практична апробація своїх можливостей;

- самовиховання професійно важливих якостей [1].

Отже, важливо навчити здобувачів освіти одержувати профорієнтаційні знання, оволодівати способами підготовки до майбутньої трудової діяльності, спрямувати їх на те, що набуті знання та вміння вони застосовуватимуть у майбутній практичній діяльності, керуватися ними. Саме це в кінцевому підсумку має призвести до обгрунтованого вибору професії.

Аналіз наукових досліджень і публікацій. Аналізуючи наукові дослідження і публікації щодо означеної проблематики, можемо констатувати посилення уваги вчених до проблеми свідомого вибору освітнього напряму. Так, Ю. Драгнєв [2] констатує, що професійний вибір передує професійному самовизначенню, яке $є$ початковим на професійному шляху майбутнього спеціаліста. О. Кучай [4] не лише характеризує професійну компетентність учителя як важливу складову розкриття свого «Я» у професії, а й здійснює порівняльний аналіз особливостей педагогічної освіти в Польщі та Україні. 
М. Фрейман [5] розглядає застосування активних методів навчання майбутніх учителів техніки й інформатики на семінарських заняттях, розкриває роль тренінгів та важливість підготовки до них студентів. Ю. Пелех та О. Юзик [6] описують діючі системи підготовки вчителів інформатики в Польщі та Україні, а також характеризують навчальні плани освітніх програм щодо підготовки вчителя інформатики у ЗВО обох держав.

Представлені вище напрями, безумовно, цікаві, однак у жодному із них не представлено дослідження, що стосується вмотивованого вибору майбутнім українським студентом спеціальності «вчитель інформатики». Саме це і стало поштовхом для написання нашої статті.

Мета статті - проаналізувати основні критерії щодо вибору випускником школи спеціальності «вчитель інформатики»; обгрунтувати результати анкетування вчителів інформатики, які працюють у 3ЗСО, щодо вибору ними майбутньої професії.

Виклад основного матеріалу. Автором статті на виконання науково-дослідної роботи з теми «Теоретичні та методичні засади підготовки вчителя інформатики в Польщі (друга половина XX - початок XXI ст.)», яку було зареєстровано в Українському інституті науково-технічної експертизи та інформації МОН України (реєстраційний номер 0116U00869; науковий керівникдоктор педагогічних наук Пелех Юрій Володимирович), було проведено анкетування серед учителів інформатики $з$ метою визначення важливості вибору ними освітнього напряму навчання, а також впливу на вибір їхньої майбутньої професії зовнішніх та внутрішніх чинників.

В опитуванні взяли участь: 25 слухачів курсів підвищення кваліфікації зі спеціальності «вчителі інформатики» (галузь знань 01 - Освіта; спеціальність 014 - Середня освіта) Закарпатського інституту післядипломної педагогічної освіти (далі - ЗОІППО); 17 слухачів курсів підвищення кваліфікації зі спеціальності «вчителі інформатики» (галузь знань 01 - Освіта; спеціальність 014 - Середня освіта) Тернопільського обласного комунального інституту післядипломної педагогічної освіти (далі - ТОКІППО); 25 слухачів курсів підвищення кваліфікації зі спеціальності «вчителі інформатики» (галузь знань 01 - Освіта; спеціальність 014 - Середня освіта) ОІППО Київського університету імені Бориса Грінченка; 19 слухачів курсів підвищення кваліфікації зі спеціальності «вчителі інформатики» (галузь знань 01 - Освіта; спеціальність 014 - Середня освіта) Рівненського обласного інституту післядипломної педагогічної освіти (далі - РОІППО); 16 слухачів заочної форми навчання (спеціальність 014 - Середня освіта (інформатика)); 11 учителів інформатики закладів загальної середньої освіти (учасники Обласного туру Всеукраїнського конкурсу «Вчитель року - 2017») спеціальності «вчителі інформатики» (галузь знань 01 - Освіта; спеціальність 014 - Середня освіта) Запорізького ОІППО. Таким чином, загалом в опитуванні брали участь 113 осіб із різних регіонів України.

Опитувальник містив 40 запитань. Опитування проводилося в письмовій формі й було анонімним (iз метою отримання від респондентів повної та відвертої інформації про стан підготовки вчителів інформатики у вітчизняних ЗВО).

На перше запитання "Який кваліфікаційний напрям (напрями) ви отримали після завершення навчання у ЗВО» опитані відповіли таким чином (див. рис.).

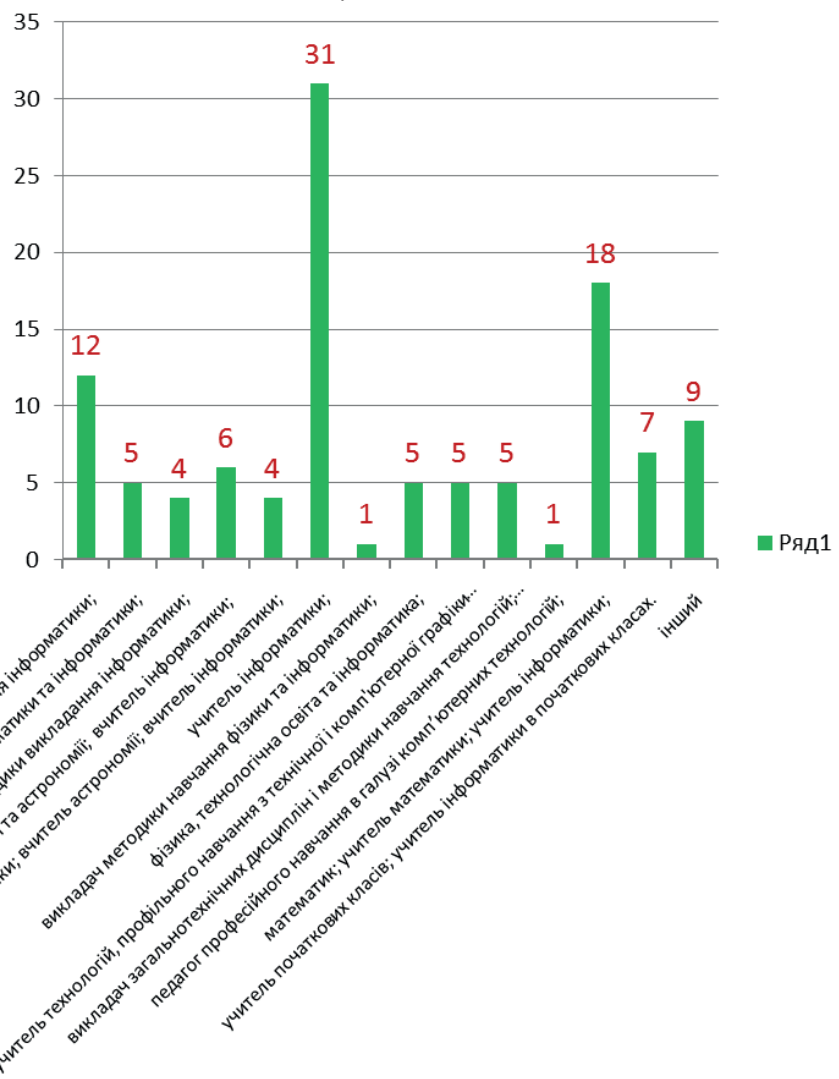

Рис. Кваліфікачійні напрями, отримані після завершення навчання у $3 В О$

Примітка. Категорія «інший» включає такі кваліфікаційні напрями: «програміст КПІ», «математик», «учитель хімії та основ інформатики», «учитель математики, математик». 
Згідно із представленими результатами відповідей найбільша кількість серед тих, хто працює в 3ЗСО за спеціальністю «вчитель інформатики», 31 особа; 18 осіб - «математик, учитель математики, учитель інформатики»; 12 осіб - «учитель математики та методики викладання інформатики».

На орузе запитання «Що спонукало вас до вибору напряму навчання?» були отримані такі відповіді: а) вирішив/ла сам/a - 78 осіб; б) вирішили (порадили) батьки - 16 осіб; в) порадили вчителі - 10 осіб; г) порадили колеги - 3 особи; г) вирішив випадок 4 особи; д) інше (зазначити) - 3 особи (серед причин вибору цього напряму навчання вони зазначили: «люблю дітей», «невідповідність наявної освіти та місця роботи», «зміна місця роботи»). При цьому, звичайно, радує те, що найбільша кількість осіб при виборі варіанту відповіді зазначили, що їхній вибір був свідомим і самостійним.

Відповідаючи на запитання «Чим ви керувалися, обираючи майбутню професію (записати значення для рішення)?», учасникам тестування слід було обрати одне зі значень для рішення: домінуюче; значне; малосуттєве; без особливого значення. відей:

При цьому були наведені дев'ять варіантів відпо-

а) «любов'ю до роботи з дітьми $і$ молоддю»: на це запитання дали відповідь 62 респонденти, зокрема 23 особи (37\%) обрали варіант відповіді «домінуюче»; 28 (46 \%) - «значне»; 7 (11\%) - «малосуттєве»; $4(6 \%)$ - «без особливого значення»;

б) «високим престижем професії»: на це запитання відповіли 59 осіб, а саме: 8 (14\%) обрали відповідь «домінуюче»; 25 (42\%) - «значне»; 19 (33\%) - «малосуттєве»; 7 (11\%) - «без особливого значення»;

в) «цікавістю напряму»: на це запитання дали відповідь 80 респондентів, зокрема 42 особи (52 \%) обрали варіант відповіді «домінуюче»; 36 (45 \%) - «значне»; 3 (3 \%) - «малосуттєве»; жоден із опитаних $(0 \%)$ - «без особливого значення»;

2) «переконаністю, щуо за циим спрямуванням легко навчатися»: загалом на це запитання дали відповідь 55 осіб, зокрема 2 особи (4 \%) обрали варіант відповіді «домінуюче»; 12 (22\%) - «значне»; 25 (45\%) - «малосуттєве»; 16 (29\%) - «без особливого значення»;

l) «вирішив випадок»: на це запитання дали відповідь 45 учасників опитування, зокрема 5 осіб (11\%) обрали відповідь «домінуюче»; 4 (8 \%) - «значне»; $11(25 \%)$ - «малосуттєве»; 25 (56 \%) - «без особливого значення»;

д) «близькістю до місия прожсивання: на дане запитання дали відповідь 53 респонденти, зокрема 4 особи (7 \%) обрали варіант відповіді «домінуюче»; $15(28 \%)$ - «значне»; 15 (28 \%) - «малосуттєве»; $19(35 \%)$ - «без особливого значення»;

е) «сімейними традиціями»: на це запитання загалом дали відповідь 50 опитаних, із яких 5 осіб (10\%) обрали варіант відповіді «домінуюче»; 9 (18\%) «значне»; 12 (24 \%) - «малосуттєве»; 24 (48 \%) - «без особливого значення»;

є) «зручним доїздом до місия навчання»: на це запитання загалом відповів 41 учасник опитування, а саме: 3 особи (8\%) обрали варіант відповіді «домінуюче»; 4 (10\% ) - «значне»; $17(41 \%)$ - «малосуттєве»; $17(41 \%)$ - «без особливого значення»;

ж) «іншими обставинами (зазначити)»: на це запитання дали відповідь 11 анкетованих, зокрема 5 осіб (44 \%) обрали варіант відповіді «домінуюче»;
$1(12 \%)$ - «малозначне»; 5 (44\%) - «без особливого значення»; жоден учасник $(0 \%)$ - «значне».

Отже, можемо зробити такі висновки: проаналізувавши варіанти відповідей за кожним запитанням, складемо таблицю ранжування:

- «Чим ви керувалися при виборі професії (записати значення для рімення)»: 80 осіб (І місце) обрали варіант відповіді «ціікавість напряму»; 62 особи (II місце) - «любов до роботи з дітьми і молоддю»; 59 осіб (III місце) - «високий престиж професії»;

- «Чи задоволені ви своєю професією?»: 26 осіб «повною мірою»; 73 особи - «швидше так»; 10 осіб - «швидие ні»; 3 особи - «зовсім не задоволений/на)» (вказати причину). Серед причин, які були вказані в анкетах, - «низька заробітна плата», «розчарування обраним фахом»;

- «При повторному виборі професії ви б обрали той самий освітній заклад? (правильну відповідь підкресліть)»: 70 осіб (62 \%) відповіли «так, той же заклад і той же напрям»; 19 осіб (17\%) - «інший заклад і той же напрям»; 14 осіб (12\%) - «той же заклад, але інший напрям»; 10 осіб (9\%) - «обрав/ла б іншу професію» (зазначити). Серед переліку професій, на які б учителі інформатики хотіли змінили свій фах, - «програміст» (2 особи), «економіст» (1 особа), «лікар» (2 особи), «ландшафтний дизайнер» (1 особа); «технолог» (1 особа).

- «Скільки років ви навчалися, здобуваючи свій фаx? Чи мали можливість застосувати свої знання на практиці? Чи відчуваєте себе підготовленим/ою) до иієї ролі?»: 62 особи (55\%) відповіли ствердно; 49 осіб (43\%) - «швидше так»; 2 особи (2\%) - «щвидше ні». Якщо опитані обирали відповідь «швидие ні», то мали пояснити причину свого вибору. Причинами відповіді були: «швидкий розвиток IT», «постійне навчання». Викликає здивування щодо вибору відповідей «так» $\mathrm{i}$ «швидше так». Хотілося б, щоб кількість відповідей «так», що стосується підготовленості випускника до ролі вчителя інформатики, була значно більшою.

- «Скільки років ви навчалися, здобуваючи фах?»: iз 17 респондентів, які взяли участь в опитуванні, 9 осіб відповіли «5 років»; 3 особи - «9 років» (4 роки в училищі +5 - в університеті); 1 особа - «7,5 років» (5 років - у педуніверситеті та 2,5 роки - в училищі); 3 особи - «6 років» (5 років і 1 рік); 1 особа «6,5 років» (5 років і 1,5 років).

Проаналізувавши відповіді респондентів, приходимо до висновку, що мотивації при виборі спеціальності «вчитель інформатики» суттєво різняться між собою. Причина цього, на нашу думку, передусім у тому, що опитані не були чіткі у своєму виборі. Це демонструють їхні відповіді щодо підготовленості випускника 3ВО до роботи за фахом, а також те, що опитувані наочно не підтвердили чіткого й одностайного вибору, зокрема відповіді «так» склали лише $43 \%$. Отже, абітурієнти, вступаючи на навчання до 3ВО, не мають чіткої орієнтації про свою майбутню професію (у нашому випадку - вчителя інформатики).

Висновки. Таким чином, вибір успішної професіїскладна, проте нагальна потреба часу. I чим швидше сучасний випускник школи поставить перед собою запитання «Чи правильним був мій вибір профілю навчання в школі?», «Чи не даремно витрачені роки навчання за обраним профілем?», «Що можна ще зробити, аби вибір професійної підготовки в закладі вищої освіти точніше відповідав моїм уподобанням, інтересам і здібностям?», тим правильнішим і більш усвідомленим буде його вибір майбутньої професії. 
Подальші наші розвідки у даному напрямі плануємо спрямувати на опрацювання анкет, які стосуються педагогічної практики, визначення ролі навчальних дисциплін у ЗВО тощо.

\section{СПИСОК ВИКОРИСТАНОЇ ЛІТЕРАТУРИ}

1. Вачевський М. В. Підготовка молоді до вибору професії в сучасних умовах / М. В. Вачевський // Молодь і ринок. - 2002. - № 1. - C. 72-75. URL: http:// tourlib.net/statti_others/vachev1.htm (дата звернення: 16.12.2019).

2. Драгнєв Ю. Професійний шлях майбутнього вчителя фізичної культури у сучасній вищій освіті / Ю. Драгнєв // Педагогіка і психологія професійної освіти. - 2012. - № 2. - С. 89-93.
3. Кінець ери освітніх дипломів. Їх відмінили. Що чекає освіту. URL: https://rezonans.cc/news/91557/ (дата звернення: 16.12.2019).

4. Кучай О. Підготовка майбутнього вчителя інформатики в Польщі та Україні: порівняльний аналіз / О. Кучай // Рідна школа. - 2011. - № 3. - С. 66-69.

5. Фрейман М. Розвиток професійної свідомості майбутніх учителів / М. Фрейман // Наук. зап. Терноп. нац. пед. ун-ту. - 2012. - № 2. - С. 95-100. - (Серія «Педагогіка»).

6. Pełech Ju. Cechy przygotowania yawodowego nauczycieli informatyki w Polsce / Ju.Pełech, O. Juzyk // Науковий вісник МНУ ім. В. О. Сухомлинського. Педагогічні науки. - 2017. - № 1 (60). - С. 262-267.

Дата надходження до редакиіï: 20.01.2020 p. 